Historia Slavorum Occidentis

2020, nr $3(26)$

ISSN 2084-1213

DOI: $10.15804 /$ hso200307

Edward Skibiński (Poznań)

ORCID: 0000-0002-3763-6817

\title{
Ars legendi. O metodzie historycznej Dariusza A. Sikorskiego ${ }^{1}$
}

W pierwszym numerze czasopisma naukowego „Historia Slavorum Occidentis” z roku 2016 ukazał się mój artykuł pt. Mieszko I: przyczynki do biografii ${ }^{2}$. Artykuł nie spotkał się wówczas z żadnym oddźwiękiem, mimo że nie był tylko powtórzeniem starych tez. Po czterech latach Dariusz A. Sikorski podjął jednak z nim polemikę. Wymaga ona wstępnego komentarza, bowiem ktokolwiek przeczyta mój tekst o Mieszku, może być zaskoczony argumentacją D.A. Sikorskiego. W artykule omówiłem źródła dotyczące Mieszka I i pozwoliłem sobie nie zgodzić się z tezami D.A. Sikorskiego. Ten brak zgody sprawil, że uznał on, iż mój artykuł jest poświęcony prawie wyłącznie jego koncepcjom. D.A. Sikorski pisze o tym wprost: „Większość tego tekstu jest polemiką z moimi poglądami”3. Sprawdziłem to. Rzeczywiście w moim tekście nazwisko Sikorski pada 35 razy, jednak imię Mieszko pojawia się 82 razy. $Z$ innych postaci z epoki: Wichman został wspomniany 36 razy, Ibrahim ibn Jakub wzmiankowany jest 43 razy, Thietmar 61, a Widukind 38 razy. Żaden nie zgłosił pretensji. Z tych wyliczeń mogę wnioskować, że nie jest to praca o D.A. Sikorskim. Z kolei w polemice D.A. Sikorskiego moje nazwisko pojawia się 70 razy, Thietmar 74 razy, Ibrahim ibn Jakub 28 razy, Widukind 29 razy, Mieszko

\footnotetext{
1 Styl polemiki D.A. Sikorskiego pomijam.

2 E. Skibiński, Mieszko I. Przyczynki do biografii, Historia Slavorum Occidentis (dalej HSO) 1 (2016), s. 15-39.

3 D.A. Sikorski, O trzech najstarszych źródłach odnoszących się do dziejów Polski raz jeszcze (polemika $z$ tekstem Edwarda Skibińskiego), HSO 1 (2020), s. 137-158, tu s. 137.
} 
19 razy, Wichman 5 razy. Wypada zatem stwierdzić, że jest to wypowiedź na temat Thietmara i Skibińskiego, jednak nie na temat mojego artykułu.

Skąd w moim tekście tak częste odwołanie do prac D.A. Sikorskiego? Na podobną sytuację skazany jest każdy, kto zajmuje się początkiem państwa Polan. D.A. Sikorski stara się wypowiadać na każdy możliwy temat dotyczący tej problematyki, a przy tym programowo próbuje podważać wszystkie dotychczasowe poglądy badaczy tego okresu. Zatem każdy, kto zajmuje się tą tematyką, musi zacząć od analizy poglądów D.A. Sikorskiego. Badanie dziejów naszego pierwszego władcy wymusza odniesienie się przynajmniej do niektórych jego pomysłów. Nie oznacza to jednak, że tematem takiego artykułu musiałyby być jedynie poglądy D.A. Sikorskiego. I tak w moim artykule zająłem się wyłącznie stosunkiem D.A. Sikorskiego do najważniejszych źródeł historycznych dla tego okresu. Takie ograniczenia narzucił mi tytuł mojego artykułu. Zajmowałem się w nim innymi zagadnieniami niż D.A. Sikorski w swoich dwóch książkach. Podejmując analizę aktywności Mieszka I w początkowym okresie jego rządów, odniosłem się najpierw do źródeł pisanych, które tę działalność komentują. Artykuł został zatem poświęcony w dużej mierze tym właśnie źródłom historycznym. W niniejszej wypowiedzi zajmę się zarzutami D.A. Sikorskiego oraz stojącą za nimi koncepcją uprawiania historii.

Polemista wykazuje się specjalnym stosunkiem do opracowań historycznych, który wymaga pewnej refleksji. Jest to stosunek, do którego analogie możemy znaleźć w pracach niektórych teologów, uważających, że powołanie się na autorytety pozwala zamknąć każdą dyskusję. Ta technika wzbudziła swego czasu protest m.in. Erazma $\mathrm{z}$ Rotterdamu, który rzucił hasło powrotu ad fontes w pracy De ratione studii ac legendi interpretandique auctores („O zasadach studiowania i czytania oraz interpretowania autorów"). W teologii ten problem już dawno mamy za sobą. Jednak w innych dziedzinach badawczych sprawia on czasem kłopot. Wynika to zapewne z pewnych zaszłości. Humanistyka pozytywnie bądź negatywnie od teologii zaczynała, nic dziwnego zatem, że przejmowała jej metody. Źródła historyczne choć w historii mają pewną rangę, czasem bywają niedoceniane. Zaczyna się to już na poziomie leksykalnym - mylenie źródeł historycznych z opracowaniami, które często też są nazywane źródłami. Te konotacje teologiczne wpływają również na to, że tego, kto odrzuca autorytety, uznaje się za heretyka, a wiadomo, jaki byłlos heretyków. W humanistyce musimy iść za klasycznym mistrzem teologii św. Pawłem, którego hasło w wersji łacińskiej brzmiało - oportet et hereses esse - „trzeba, żeby były również różnice”.

Spróbujmy zatem rozpatrzyć całą sprawę po kolei. W moim tekście, omawianym przez D.A. Sikorskiego, na wstępie przedstawiłem źródła historyczne dotyczące 
Mieszka I i przedyskutowałem ostatnie koncepcje na ich temat. Historyk musi wyznaczać sobie ramy swojej pracy, bo nie może zajmować się wszystkim. Źródła, które omawiałem, nie dotyczyły wyłącznie początków Polski. Mieszko I nie tylko nie był ich głównym tematem, lecz nawet nie był jednym z ważniejszych. Były to głównie teksty kronikarzy saskich i geografów arabskich. Sasi, podobnie jak inni kronikarze średniowieczni (również i nasi), w niewielkim stopniu interesowali się sąsiadami. Ponadto pismem posługiwano się rzadko, nie tylko dlatego, że środki pisarskie były drogie. Pisma wymagała sfera religijna, z czasem także najwyższa władza, stąd też pisarzami bywali najczęściej duchowni. Prawdziwa kultura pisma istniała natomiast w krajach muzułmańskich. Dla podróżników przybyłych stamtąd Europa Łacińska była jednak dosyć prymitywna.

Tytuł mojego artykułu przez wskazanie na postać Mieszka I wyznaczał ramy analizy źródeł historycznych, których teksty interesowały mnie jedynie w takim zakresie, w jakim odnosiły się do poruszanego przeze mnie tematu. Nie analizowałem zatem całego dzieła Widukinda czy Thietmara. Nie odniosłem się również do wszystkich relacji przypisywanych Ibrahimowi ibn Jakubowi. Chociaż omówiłem także inne źródła, to D.A. Sikorskiego zbulwersowała wyłącznie analiza tych trzech wyżej wymienionych. Pominął moje uwagi na temat tzw. epitafium Bolesława Chrobrego. Polemizuje zatem z moim ujęciem trzech jedynie źródeł: Dziejów Sasów Widukinda, Kroniki Thietmara oraz tzw. Relacji o Stowianach Ibrahima ibn Jakuba. Ta ostatnia ma szczególny charakter, gdyż nie zachowała się w oryginale. Jej treść przekazał jeden z najsławniejszych geografów Andaluzji, żyjący w XI w. al-Bekri. Tekst ten wydał nasz znakomity arabista i turkolog Tadeusz Kowalski. O tej edycji napisał D.A. Sikorski tak: „Zarówno edycja, jak i komentarz są z punktu widzenia historyka niearabisty pełne niedostatków, utrudniających korzystanie ze źródła”. Krytyka edycji tekstu arabskiego sformułowana przez niearabistę nie została jednak wzbogacona o argumenty - nie wiemy zatem, jakie T. Kowalski popełnił błędy w swojej pracy. D.A. Sikorski postanowił zakwestionować dotychczasowe ustalenia nauki historycznej w oparciu o nowe opracowania, które pojawiły się w nauce europejskiej, jak to widać z jego polemiki. Warto na początku podkreślić różnicę, jaka zachodzi między przyjmowanymi przez D.A. Sikorskiego i przeze mnie stanowiskami. Jako mój krytyk, skoncentrował się on na publikacjach, które uznał za literaturę przedmiotu i to taką, która jeszcze nie była wykorzystywana przez badaczy. To stosunek do literatury przedmiotu różni nasze stanowiska (poza stylem wypo-

4 D.A. Sikorski, Początki Kościoła w Polsce, Poznań 2012, s. 21. 
wiedzi). Wedle mej opinii wartość literatury przedmiotu dla dyskusji wynika z tego, jak dalece uwzględnia ona podstawę źródłową. Nie ma jednak ona znaczenia samodzielnego. Odróżniam zatem źródła i literaturę przedmiotu. W przeciwieństwie do źródeł opracowania starzeją się szybciej. Stanowisko badaczy w dyskusji jest o tyle ważne, o ile dotyczy tematu dyskusji. O ile historia historiografii zajmuje się całością konstrukcji wypracowanych przez historyków, o tyle historia właściwa odnosi się do nich tylko w takim stopniu, w jakim odnoszą się one do źródeł historycznych. Stąd moje stanowisko badawcze - nie pracuję bowiem w dziale opracowań, lecz w zakładzie źródłoznawstwa i nauk pomocniczych historii.

W sprawie Ibrahima ibn Jakuba odrzuciłem w moim artykule konstrukcje D.A. Sikorskiego (nie tylko jego) z takim uzasadnieniem: „Zatem D.A. Sikorski tworzy ogniwa pośrednie między Ibrahimem ibn Jakubem a przekazem al-Bakriego za pomocą tekstów, co do których nie ma żadnych śladów i przesłanek, by zawierały jakiekolwiek informacje o świecie słowiańskim”. Myślę, podobnie jak mój adwersarz, że źródłem nieporozumień między nami jest niestaranna lektura źródeł i opracowań. Podstawowe opracowanie dotyczące słowiańskiej tematyki przypisywanej Ibrahimowi ibn Jakubowi, a więc tekst Andrzeja Zaborskiego, właściwie nie zostało przez D.A. Sikorskiego skomentowane i pojawia się w jego książce zaledwie pięć razy.Jedyne, co D.A. Sikorski z niego wyczytał, to obrona wydania Ibrahima ibn Jakuba przygotowanego przez Tadeusza Kowalskiego. Gdyby chociaż D.A. Sikorski poszedł tym śladem i zbadał, jaka jest recepcja tego wydania... Tego jednak nie uczynił. Nie zapoznał się więc ze stanem badań w najbardziej podstawowym stopniu. Przyjrzyjmy się zatem, temu co napisał:

Powodem głębszego, niż do tej pory czynili polscy historycy, prześledzenia stanu badań nad dziełem al-Bakriego i miejscem w nim tzw. Relacji ibn Jakuba była moja konstatacja sprzed ponad dekady, że od publikacji przez Tadeusza Kowalskiego edycji krytycznej rozdziału „O Słowianach” al-Bakriego minęło 70 lat, a od opublikowania źródłowego wprowadzenia przez G. Labudę, w którym stanowiono „kanoniczne” poglądy odnośnie różnych kwestii źródłoznawczych, upłynęło zaledwie dekadę mniej'.

Zdanie ciekawe, acz nieprawdziwe - biorąc pod uwagę, że publikacja T. Kowalskiego ukazała się w 1946 r., a recenzja Labudy w 1947 r., dekada zaś, przypomnijmy, oznacza dziesięć lat. Trudno też zaakceptować tezę, że „kanoniczne” (terminologia kościelna D.A. Sikorskiego) poglądy źródłoznawcze ustanawiał G. Labuda. Nie da

5 E. Skibiński, Mieszko I, przyczynki do biografii, s. 15-39, 20.

6 D.A. Sikorski, O trzech najstarszych źródłach, s. 137-158, tu s. 138. 
się bowiem przeprowadzić analizy źródłoznawczej, nie znając języka źródła. „Kanoniczne" w tym sensie mogą być tylko opinie T. Kowalskiego. Dalej polemista przedstawia moje rzekomo błędne poglądy. Najpierw, tylko w przypisie, zwraca uwagę na używaną przeze mnie błędną wersję imienia arabskiego autora: „Autor używa zamiennie formy al-Bekri i al-Bakri z preferencją dla tej pierwszej. Ta zaś, mimo że zasiedziała w starszej historiografii polskiej i siłą rozpędu chyba utrzymana w edycji Kowalskiego jest dzisiaj zarzucona"7. D.A. Sikorski zdaje się kreować tu na autorytet. Są jednak i inne. Wersji Al-Bekri używa wydawca relacji Ibrahima ibn Jakuba T. Kowalski w swojej edycji. Używa jej też A. Zaborski w swoim omówieniu stanu badań nad relacją Ibrahima, którą D.A. Sikorski czytał, ale tego nie zauważył: „Wątpliwa jest zastosowana przez T. Lewickiego wokalizacja „Mišqa (to jest forma czysto hipotetyczna, a przy tym brzmiąca nachalnie z rosyjska) oparta na regułach arabskiego języka klasycznego (w X w. już martwego) i nieznajomość allofonów, czyli wariantów samogłosek arabskich. Nota bene, prof. Kowalski też pedantycznie trzymał się reguł klasycznych, ale wyjątkowo używał zadomowionej już formy alBekri zamiast klasycznego al-Bakri"'.

D.A. Sikorski zaczyna od tytułów dzieł arabskich:

E. Skibiński stara się mnie pouczyć, że „Wypada najpierw zauważyć, że al-Udhri nie napisał dzieła Kitāb al-Masālik wa 'lMamālik, lecz inne, pt. Tarsi al-ajbar bądź też Nizam al-murdjan” (s. 18). Otóż Autor nie wie, że oryginalne tytuly dzieł arabskich są bardzo rozbudowane. Często średniowieczni autorzy arabscy wykorzystując czyjeś dzieło stosowali skróty podobnie jak czynią współcześni badacze. Właściwy tytuł dzieła al-Udhriego - tak, jak go potrafimy zrekonstruować - to Kitāb tarșī al-ajbār wa-tanwīi al-ābār wa-l-bustān fī garāib al-buldān wal-masālik ilà ŷamī‘ al-mamālik. Pod tytułem Tarsi al-ajbar... (Skibiński korygując mnie nie podaje całości tytułu w tej wersji!) został wydany fragment z dzieła al-Udriego, bo tak jest zatytułowany w wykorzystanym w edycji rękopisie?

W całym tym rozumowaniu nie ma jednak dowodu na to, że dzieło al-’Udrīego nosiło taki tytuł, jak to podał D.A. Sikorski. W zamian zaś przedstawił dość dziwaczne komentarze. Jak je rozumieć? Najpierw więc przyjmijmy opcje Autora. Ła-

7 Tamże, s. 140.

8 A. Zaborski, Bilans i przyszłość badań nad tekstem Ibrahima Ibn Jakuba, [w:] Ibrahim Ibn Jakub i Tadeusz Kowalski w sześćdziesiąta rocznicę edycji. Materiały z konferencji naukowej Kraków, 10 maja 2006 r., red. A. Zaborski, Kraków 2008, s. 25-73, tu s. 42.

9 D.A. Sikorski, O trzech najstarszych źródłach, s. 139. 
two zobaczymy, że mają one swoje konsekwencje - przyjmując jego logikę należy wprowadzić istotne modyfikacje do naszych wypowiedzi na tematy literackie. Mówiąc np. że Adam Mickiewicz napisał Pana Tadeusza, dajemy świadectwo własnej ignorancji - bo przecież dzieło Adama Mickiewicza nosi tytuł Pan Tadeusz, czyli Ostatni zajazd na Litwie: historia szlachecka $z$ roku 1811 i 1812 we dwunastu księgach wierszem. Jednak dla tradycjonalistów, którzy uważają, że jest uprawnione używanie skróconych tytułów, ważniejsza jest druga część argumentacji D.A. Sikorskiego. Zatem czy Tarsi al-ajbar - czy też Kitāb tarṣī‘ al-ajbār. Różnica leży w słówku kitab - które oznacza księgę i jest odpowiednikiem łacińskiego liber. D.A. Sikorski przyznaje mi więc rację, mimo że się ze mną nie zgadza.

Zobaczmy dalej, jak objaśnia tytuł dzieła al-Uddriego: „Często tytułowali jego dzieło inaczej niż twierdzi Skibiński np.: Nizāām al-marŷān fīl - masālik wa-l-mamālik. Tę ostatnią formę używał m.in. wybitny arabista É. Lévi-Provençal, ale np. al-Qazwini tytułował je al-Mamālik wa 'l-masālik al-Andalusīya. Użyta przeze mnie forma jest jedną z kilku spotykanych w literaturze" ${ }^{10}$. D.A. Sikorski traktuje tu opinię badacza jako źródło historyczne - co jest wadą całej jego argumentacji. Formę, którą używał Évariste Lévi-Provençal, podał nam Jakut Ibn Abdallah al-Hamawi w swoim wielkim dziele Kitāb Mu'jam al-Buldān. Tytuł podany przez al-Qazwiniego - oznacza Drogi i królestwa Andaluzji. Zawęża więc zakres dzieła al’’Ud́rīego - w tej wersji nie należy do niego np. Słowiańszczyzna. Dodajmy jeszcze, że É. Lévi-Provençal pisze o tym na s. XXIV, a nie - jak podaje D.A. Sikorski - na s. XXII. Jest to jedyne odwołanie do dzieła al-'Udrīego w tym tomie. Pisze o nim É. Lévi-Provençal tak: „Ce personnage, qui vivait au XI ème siècle de notre ère, écrivit, si l'on en croit l'un de ses biographes, un ouvrage géographique intitulé Nizam al-margan f ' 'l-mamālik wa-l-masālik, qui semble bien, dès lors, avoir été mis largement a profit par son contemporain, compatriote et disciple Abū “Ubaid al-Bakrī”. Francuski badacz zaznacza więc, że te szczegóły znamy $\mathrm{z}$ drugiej ręki i nie traktuje ich jako pewników, jakby chciał D.A. Sikorski. W przypisie na s. 39 pisze D.A. Sikorski: „Już pełny tytuł edycji krytycznej zachowanego fragmentu sugeruje, co uważał wydawca za tytuł pełnego dzieła: »Ahmad Ibn 'Umar Ibn Anas al'Uḍī. Nușūṣ 'an al-Andalus. Fragmentos geográfico-históricos de Al-Masālik ilà ŷamī' al-Mamālik«, ed. 'Abd al-Azīz al-Ahwānī, Madrid 1965”"11. Tyle Uczony. Ale co znaczy ten tytuł? Aḥmad Ibn 'Umar Ibn Anas al-'Udrī - to jest autor, a nie część tytułu. Następnie - Nușūṣ , an al-Andalus to „Teksty o Al-Andalus”. Kolejna część - „Fragmentos

10 Tamże, s. 140.

11 Tamże, s. 139-140. 
geográfico-históricos de Al-Masālik ilà ŷamī al-Mamālik” - oznacza „Fragmenty geograficzno historyczne” - „Al-Masālik ilà ŷamī al-Mamālik” to „Szlaki do wszystkich królestw”. „Fragmentos...” jest to tytuł nadany przez wydawcę, który ma świadomość, że wydał tylko fragmenty. Nawet jeśli się nie zna arabskiego, to w tej części „tytul” brzmi nie-arabsko.

Dalej pisze D.A. Sikorski tak: „Z dalszych wypowiedzi E. Skibińskiego wynika, że w ogóle neguje on zależności al-Bakriego od al-Udhriego (nie tylko w rozdziale „O Słowianach”). Pogląd ten stoi w sprzeczności do całości piśmiennictwa historycznego zajmującego się tym problemem" ${ }^{12}$. Jednak nie przeczytał dokładnie mojego artykułu. Napisałem bowiem: „W zachowanym dziele al-Udhriego nie ma fragmentów relacji o Słowianach Ibrahima, przekazanej w tekście al-Bekriego. Jest to zarzut poważny - al-Bekri mógł wykorzystać al-Udhriego w innych częściach swojego dzieła, jednak nie w części poświęconej Słowianom” ${ }^{13}$. W swoim artykule wypowiedziałem się też o zależności dzieła al-Bekri i al-'Ud̆riego: „Rozumowanie przedstawione przez D.A. Sikorskiego o zależności obu autorów nie ma niestety podstawy źródłowej. Abū 'Ubayd al-Bekri powołuje się wyraźnie na Ibrahima ibn Jakuba, a nie na al-Udhriego" ${ }^{14}$. D.A. Sikorski pospieszył z korektą:

Błąd E. Skibińskiego polega na tym, że potraktował występowanie w tekście al-Bakriego tzw. isnad - czyli wskazania autorytetu lub łańcucha pośredników w przekazie rękopiśmiennym, a często również ustnym, na który autor dzieła się powołuje - zdroworozsądkowo i dosłownie. Nie jest mu znana praktyka piśmiennictwa arabskiego polegająca na zaznaczaniu niekoniecznie bezpośredniego tradenta, który został wykorzystany, ale właściwego autora pierwotnego źródła danej informacji, nawet jeśli autor odwołujący się w isnadzie nie miał do niego bezpośredniego dostępu i korzystał ze źródła pośredniego ${ }^{15}$.

D.A. Sikorski wynalazł nowy rodzaj argumentacji recenzyjnej - zamiast obalać argumenty i czytać uważnie omawiany tekst, zarzuca autorowi niekompetencję. Objaśniając swoje stanowisko, napisałem zdanie, którego D.A. Sikorski nie zrozumiał. Powtórzę je więc i objaśnię: „W metodyce historycznej mamy tu więc fakt źródłowy, którego nie znalazł dla swojej argumentacji D.A. Sikorski”16.

\footnotetext{
12 Tamże, s. 140.

13 E. Skibiński, Mieszko I: przyczynki do biografii, s. 18.

14 Tamże, s. 18.

15 D.A. Sikorski, O trzech najstarszych źródłach, s 140-141.

16 E. Skibiński, Mieszko I: przyczynki do biografii, s. 19.
} 
Pojęcie faktu źródłowego wprowadził (choć, jak sam twierdził, nie wymyślił) Gerard Labuda. Faktem źródłowym nazywamy każde zdarzenie zapisane w źródłach, każde poświadczenie najprostszych działań - faktem takim jest zarówno wzmianka o chrzcie Mieszka I, jak i opowieść o smoku wawelskim w Kronice Polskiej mistrza Wincentego. Uczę czytać przekaz historyczny w całości, bez usuwania elementów fantastycznych czy nieprawdziwych. Opowiadanie o rzeczywistości nie musi być prawdziwe, ale tworzy rzeczywistość minioną. Mówimy o niej, bo mamy takie źródła. Na ich podstawie dokonujemy interpretacji. W tekście al-Bekriego jest wskazanie na Ibrahima ibn Jakuba jako źródła relacji o Słowianach. Nie ma natomiast powołania na al-'Udrīego w tym miejscu. Nie ma też żadnych innych źródeł, w których byłaby na ten temat wzmianka i D.A. Sikorski również takich nie przedstawil, więc oczywiście nie mam podstaw do zmiany opinii. Argumentację przedstawił natomiast Andrzej Zaborski w przywoływanym i niedoczytanym przez D.A. Sikorskiego artykule:

Wspomnę tutaj, że autorzy wydania z 1992 roku tj. Van Leeuven i Ferré piszą w swoim „Wstępie” (Van Leeuven, Ferrè 1992: 23), iż „jest także bardzo prawdopodobne, że fragmenty Relacji Ibrahima ibn Jakuba, które przekazuje al-Bekri pochodzą z dzieła al-Udriego" ale nie podają żadnego argumentu i tylko w odsyłaczu wspominają, że al-Qazwini cytuje za al-Ud̆rim szereg ustępów pochodzących z Relacji Ibrahima ale to nie jest żadnym dowodem ani nawet podstawą dla jakiejś rozsądnej hipotezy ${ }^{17}$.

Żadnej polemiki z tą tezą A. Zaborskiego Polemista nie przedstawił. Przyjrzyjmy się jednak kolejnym argumentom D.A. Sikorskiego:

Sprawa wartości informacyjnej isnad w rozdziale „O Słowianach” al-Bakriego była zresztą poruszana przez samego T. Kowalskiego. Zwrócił on uwagę, że w dociekaniach nad problemem czy al-Bakri miał do dyspozycji tekst tzw. „Relacji” ibn Jaukba czy korzystał z niej za pośrednictwem innego dzieła, np. al-Udhriego, nie można się sugerować odwołaniem przez al-Bakriego bezpośrednio do ibn Jakuba. Dał przykład, jak w działach al-Qazwiniego i al-Himyarego, w partiach, które pochodzą od ibn Jakuba, jako źródło podany jest właśnie ibn Jakub, chociaż żaden z nich nie miał tego tekstu w rękach. W innym miejscu, również w partii pochodzącej z Relacji ibn Jakuba, podany jest właściwy tradent - al-Udhri ${ }^{18}$.

\footnotetext{
17 A. Zaborski, Bilans i przyszłość badań, s. 25-73, tu s. 31-32.

18

D.A. Sikorski, O trzech najstarszych źródłach, s. 141.
} 
Odwołuje się tu autor do s. 39 wydania „Relacji” Ibrahima ibn Jakuba w wydaniu T. Kowalskiego. Zasadnicza interpretacja tekstu T. Kowalskiego dokonana przez D.A. Sikorskiego jest błędna. T. Kowalskiemu chodziło o wiarygodność twierdzenia Himjariego, że Ibrahim ibn Jakub rozmawiał z al-'Udnīm. Uznał to za niemożliwe ze względu na daty życia obu autorów. Zatem zdarzenie nie mogło się odbyć - jednak autor mógł, wypisując z al-’Ud drīego, pominąć wymienione przez tego ostatniego źródło (tradenta - czyli przekaziciela informacji). Chodzi więc o Himjariego, a nie al-Bekriego. Wskazałem następnie, że opierając się na chronologii, możemy przyjąć, że al-Bekri napisał swoje dzieło przed al-’Udrīm. D.A. Sikorski jak w całej swojej polemice pominął i tu argument, z którym nie mógł sobie poradzić i polemizuje $\mathrm{z}$ trzema linijkami tego ustępu.

Zacznijmy od wyjaśnienia zależności między oboma uczonymi. Sprawę twierdzenia, że al-Bekri był uczniem al-’Uḍīego można objaśnić, sięgając do znanych przykładów. Jak wspomina I. Kreczkowski (s. 273-274), al-’Udrī nazywał siebie uczniem Ibn Abd Al-Barra i jednocześnie byl jego mistrzem, wedle ówczesnego obyczaju - ten, kto słucha wykładów mistrza, staje się jego uczniem (za Yaqutem). Oczywiście dzieło/dzieła al-'Uḍriego były wykorzystywane przez al-Bekriego i zapewne wzajemnie al-'Ud drī skorzystał ze współpracy z al-Bekrim. Propozycję rozwiązania przynosi cytowany przez D.A. Sikorskiego artykuł Manuela Sáncheza Martíneza pt. Rāzī, fuente de al-'Udrī para la España pre-islamica ${ }^{19}$, w którym na s. 13 znajdujemy tezę, że w czasie spotkania w Almerii al-Bekri i al-'Ud̆rī wymienili się notatkami do swoich prac. Al-Bekri miał przekazać swoje notatki, które zebrał w czasie studiów w Kordobie pod kierunkiem słynnego Ibn Hayyana ${ }^{20}$. Pytanie, gdzie ostatecznie napisał swoje dzieło geograficzne, może być rozmaicie rozstrzygane. Jedna z propozycji badacza twórczości arabskiego geografa i uczonego została tak ujęta przez wydawczynię i tłumaczkę dzieła al-Bekriego. Samia Bouamrane następująco podsumowała swoje poglądy na temat miejsca powstania „Kitâb al-Massâlik wa-l-Mamâlik”: „Abû Ubayd Allah al-Bakrî est l'une des figures les plus représentatives de la civilisation arabo-andalouse. Né en $405 \mathrm{H} / 1014$, il est issu d'une famille de notables, son père est gouverneur de deux petites principautés, non loin de Cordoue. C'est dans cette ville qu'il vit et compose son oeuvre"21.

19 M. Sánchez Martínez, Razi, fuente de al-'Udri para la Espana preislamica, Cuadernos de Historia del Islam, 3 (1971), s. 8-49.

20 Abū Marwān Ḥayyān ibn Khalaf ibn Ḥusayn ibn Ḥayyān al-Qurțubī (987-1075).

21 S. Bouamrane, Andalous et Almoravides à l'époque d'Al-Bakrî (5èH/11è s.ap.J.C.), Revue des Sciences Humaines - Université Mohamed Khider Biskra, No: 23, s. 60. 
Krytykę kolejnego punktu mojego artykułu wyraził D.A. Sikorski w ten sposób:

Proponowałem, by postulowanym pośrednim źródłem między Relacją Ibrahima ibn Jakuba i al-Udhrim był Isa al-Rāzī. Skibiński stwierdził, że „Isa ar-Razi, wskazany przez D.A. Sikorskiego, był historykiem zajmującym się dziejami muzułmańskiej Hiszpanii i jej władców i nic nie wiemy o jego zainteresowaniach środkową Europą (s. 20). Skibiński przypisuje mi cudzy pomysł. Ignoruje fakt wyrażony przypisem, że w tym zakresie opieram się na wnioskach historyka i arabisty Jerzego Hauzińskiego ${ }^{22}$.

Jak to już wcześniej pokazałem, tak i tu D.A. Sikorski, interpretując mój tekst, jak się zdaje, niezbyt dobrze go rozumie, podobnie jak i własny tekst. Bowiem pomysł J. Hauzińskiego to on właśnie zaakceptował i rozwinął w postaci całego wywodu filiacji przekazu Ibrahima ibn Jakuba niepomny na przytoczone przez siebie słowa J. Hauzińskiego: „W sytuacji nikłej dostępności materiałów źródłowych z obszaru hiszpańskiego islamu kwestia ta jest otwarta, nie wychodząc poza status ogólnikowej hipotezy”23. Sam pomysł oparł J. Hauziński na takiej tezie: „Ważnym śladem byłaby tu wiadomość dziejopisa Ibn Ḥayyāna (ok. 988-1076) utrzymującego, że 'Īsa ar-Rāzī posługiwał się jakimiś osobistymi raportami sporządzanymi dla kalifa Al-Hakama II, a więc protektora naszego podróżnika" ${ }^{24}$. Tu J. Hauziński odwołuje się do pracy Konstantina A. Bojko, jednak niedokładnie. K.A. Bojko pisze bowiem, że Isa spożytkował jakieś zapiski kalifa Al-Hakama II, i dodaje, że być może były to notatki na marginesach rękopisu sporządzone $w$ trakcie lektury ${ }^{25}$. Nie mogą to być zatem raporty jego wysłanników. Podsumowując, D.A. Sikorski oparł się na wypowiedzi J. Hauzińskiego, której dokładnie nie przeczytał. Nie zweryfikował też podstawy tego pomysłu. Cała konstrukcja jest jednak autorskim wynalazkiem D.A. Sikorskiego pozbawionym zupełnie podstawy źródłowej.

Swoje rozumowanie próbuje dalej Polemista oprzeć na jakimś opracowaniu:

Zresztą obaj, ojciec i syn, byli aktywnymi uczestnikami życia dworu kalifów i wykazywali zainteresowanie kontaktami kalifów z Frankami i Niemcami. İsa

\footnotetext{
22 D.A. Sikorski, O trzech najstarszych źródłach, s. 143.

23 Tamże, s. 144.

24 J. Hauziński, O potrzebie nowej edycji Ibrāhīma Ibn Ya'qūba Aț-Turtūšī o krajach Środkowej Europy, [w: Z Mekki do Poznania. Materiaty 5. Ogólnopolskiej Konferencji Arabistycznej Poznań, 9-10 czerwca 1997, red. H. Jankowski, s. 105-113, tu s. 109.

25 K.A. Bojko, Arabskaja istoričeskaja literatura v Ispanii (VIII-piervaja tret' XI v.), Moskva 1977, s. 131.
} 
al-Rāzī wspomina np. o posłannictwie wysłanym w 974 r. przez Ottona, a w Relacji Ibrahima w przekazie al-Qazwiniego słyszymy, że Otton I wyraził taki właśnie zamiar! Mimo że mało zachowało się z jego pism, to wiemy, że Îsa al-Rāzī śledził to, co dotyczyło ówczesnych Niemiec ${ }^{26}$.

Cytowany tu na poparcie tezy D.A. Sikorskiego Daniel G. König pisze jednak tak ${ }^{27}$ :

Ibn Hayyān, however, who also bases much of what he says on Ahmad al-Rāzi and his son 'Īsā, mentions another embassy sent by a Frankish king called Otto (Hūtū, malik al-Ifranj) for the year 363/974. If we could clearly identify this „Hūtū” with Otto I (d. 973) or Otto II, Ibn Hayyān's text would prove that the Ottonian realm was occasionaly also regarded as Frankish by Andalusian historiographers. However, this interpretation is refuted by 'Abd al-Raḥmān 'Alī al-Hajji who belives that „Hūtū” stands for the Western Frankish king Hugh Capet.

Ponownie D.A. Sikorski nie przeczytał dokładnie tekstu, na który się powołał. Dodajmy, że 'Abd al-Raḥmān 'Alī al-Hajjī jest właśnie wydawcą tekstu Ibn Ḥayyāna. Przede wszystkim nie ma tu mowy o tym, że Ibn-Hayyān opiera się na Aḥmad al-Rāzi i jego synu 'Īsāa akurat w tym miejscu swojego tekstu. Jak więc widać, D.A. Sikorski zbyt pobieżnie przegląda swoje opracowania, co sprawia, że nie potrafi zreferować ich treści. Marginalną z punktu widzenia tez D.A. Sikorskiego sprawą jest, że autor cytowanej pracy zajmuje się relacjami muzułmańskich intelektualistów dotyczącymi zachodniej Europy, a nie Słowiańszczyzny, co było tematem moich zainteresowań w dyskutowanej przez niego pracy.

D.A. Sikorski w poszukiwaniu autorytetów (a nie źródeł) osiągnął jednak pewien sukces. Znalazł mianowicie autora, który przedstawił podobną hipotezę:

Mogę tylko dodać, że w 1982 r. kataloński historyk-arabista Pere Balañà i Àbadia doszedł do takich samych wniosków w kwestii zależności poszczególnych tradentów. Relacji ibn Jakuba, jakie przedstawiłem w 2012 r. na podstawie opinii zaczerpniętych z literatury przedmiotu. Wówczas pracy tej nie znałem. Wnioski tego badacza są o tyle cenne, że podbudowane zostały argumentacją wynikającą z analizy tekstów (nie trzeba chyba dodawać, że oryginalnych), a nie wyłącznie literatury, jak w moim przypadku. Ów badacz nie porusza jedynie

\footnotetext{
26 D.A. Sikorski, O trzech najstarszych źródłach, s. 144.

27 D. König, Arabic-Islamic Views of the Latin West. Tracing the Emergence of Medieval Europe, Oxford 2015, s. 282.
} 
problemu identyfikacji ewentualnych źródeł pośrednich między ibn Jakubem a al-Udhrim, ale uznaje istnienie takiego pośrednictwa ${ }^{28}$.

Sięgnijmy zatem do artykułu P. Balañà i Àbadia, „Un Jueu de Tortosa (segle Xè) informador dels geògrafs àrabs medievals" ${ }^{\prime 29}$, gdzie na s. 21-22 znajdujemy takie podsumowanie argumentacji autora: „Tanmateix nosaltres no considerem encertada cap de les dues possibilitats. La primera perquè sabem molt bé que al-Bakrī fou deixeble d’al-Udri i no és lògic que el deixeble accedís al text original d’al-Ṭurțūisī i el mestre es limités a estudiar-lo sobre una obra de segona mà”30. Autor tłumaczy tu, że nie jest logiczne, żeby uczeń miał dostęp do tekstu Ibrahima, a nauczyciel studiował go z drugiej ręki. D.A. Sikorski rzeczywiście znalazł autora, który podobnie jak on argumentuje, ale nie jest to argumentacja historyczna. Tak może argumentować krytyk literacki, oceniając czyjąś powieść, twierdząc, że autor źle skonstruował fabułę. P. Balañà i Àbadia nie zna i nie uwzględnia wydania T. Kowalskiego i ma niewielkie pojęcie o zachowanych rękopisach al-Bekriego. Nie zna też dyskusji na temat Relacji ibn Jakuba o Słowianach. Argumentacja w artykule jest źle skonstruowana i nie dotyczy naszego tematu. Autor nie zajmuje się relacją o Słowianach. Jednak nie wszystkie moje argumenty D.A. Sikorski odrzucił: „W jednym punkcie krytyki Skibińskiego przyznaję mu rację (s. 22 n.). Chodzi o przypisanie przeze mnie T. Lewickiemu opinii, której w cytowanej przeze mnie jego pracy nie ma, a była istotnym elementem mojej argumentacji. Mój błąd" ${ }^{\text {. }}$. D.A. Sikorskiemu chodzi tu o nazwę Kraków w Relacji Ibrahima, którą zakwestionował w swojej pracy. Jak widać wycofał się z tej tezy. Krakowiacy mogą spać spokojnie. Jednak podważanie edycji T. Kowalskiego było częścią argumentacji D.A. Sikorskiego, który starał się zakwestionować argumenty o przynależności Krakowa do Czech oparte o tekst Ibrahima. Zapoznawszy się z literaturą przedmiotu i argumentacją D.A. Sikorskiego, uznałem, że autor nie przeczytał artykułu A. Zaborskiego, który stanowi krytyczne omówienie dotychczasowej dyskusji tej problematyki. Z jego argumentacji omówił D.A. Sikorski niewiele. Widać nie trafiła do przekonania. Śladu przemyśleń D.A. Sikorskiego na temat tez A. Zaborskiego nie znajdziemy w jego książce, nie widać ich też w polemice. Zawsze można dyskutować o tym, kiedy powstały dzieła al-Bekriego, czy al-'Udrīego. Jednak nie na podstawie haseł w encyklopediach i literatury

\footnotetext{
28 D.A. Sikorski, O trzech najstarszych źródłach, s. 146-147.

29 P. Balañà i Àbadia, Un Jueu de Tortosa (segle Xè) informador dels geògrafs àrabs medievals, Quaderns d'Historia Tarraconense 3 (1982), s. 9-28.

30 Tamże, s. 21-22.

31 Tamże, s. 147.
} 
przedmiotu, tylko źródeł historycznych - nawet w tłumaczeniach. Tego D.A. Sikorski nie robi. Nawet bowiem, gdybyśmy udowodnili bliską znajomość obu autorów, to i tak nie byłby to dowód na poparcie tezy D.A. Sikorskiego. Ten może być jeden - świadectwo źródeł.

D.A. Sikorski nie wykazał się znajomością najprostszych opracowań, dotyczących mojego tematu. Dysponujemy opracowaniami o Słowianach w świecie muzułmańskim, o czym piszą Mahomed Meouak ${ }^{32}$ i Dmitrij Jewgienjewicz Miszyn ${ }^{33}$. Ten ostatni poświęcił też odrębną pracę Ibrahimowi ibn Jakubowi ${ }^{34}$. Opracowania te są przydatne, bo zajmują się konkretnymi aspektami tekstu, który jest właśnie dla nas źródłem historycznym do najstarszych dziejów Polski. D.A. Sikorski polemizował ze mną również na temat języka tekstu al-Bekriego:

E. Skibiński twierdzi: „Ponieważ nigdzie nie mamy zachowanego odpisu Relacji ibn Jakuba, nie ma podstaw do dalszych hipotez" (s. 18). Jest to nieprawda. W dziełach kilku autorów arabskich zachowały się fragmenty Relacji ibn Jakuba, które wprawdzie - poza zachowanym fragmentem al-Udhriego o Lorce - nie zostały odpisane z oryginalnego dzieła, ale odzwierciedlają etapy jego recepcji w późniejszym piśmiennictwie.

Co na to inni badacze? Zwrócił uwagę na ten problem D.J. Miszyn: „As for the passages about Western Europe, they are very different from the description of the Slavs. All of them deal with wonders: in Fulda, it is a statue of the Crucifixion; in Rouen, a person with a long beard; in Schleswig, a feast. The language is very different as well" ${ }^{35}$. Tę tezę podtrzymał również w swojej monografii, stwierdzając, że $R z e c z$ o Stowianach jest pióra al-Bekriego, a nie Ibrahima ibn Jakuba ${ }^{36}$.

Doświadczenie tej polemiki pokazuje, że stan badań nad arabską tradycją intelektualną średniowiecza, a także - co dla nas ważne - nad geografią średniowieczną ciągle jeszcze nie ma pełnych opracowań. Nie jest to nic dziwnego. Podobnie jest z badaniami nad spuścizną łacińską średniowiecza. Prowadzi to jednak do niepo-

\footnotetext{
32 M. Meouak, Şaqāliba, eunuques et esclaves à la conquête du pouvoir. Géographie et histoire des élites politiques "marginales" dans l'Espagne umayyade, Saarijärvi 2004.

33 А.Е, Мишин, Сакалиба (славяне) в исламском мире в раннем средневекове, Москва 2002.

34 D. Mishin, Ibrahim ibn Ya'qub At-Turtushi's Account of the Slavs from the Middle of the Tenth Century, Annual of Medieval Studies at the CEU 1994-1995, Budapest 1996, s. 184-199.

35 Tamże, s. 194.

36 А.Е. Мишин, Сакалиба (славяне) в исламском мире в раннем средневекове, s. 35.
} 
rozumień, z których należy sobie zdawać sprawę. Wskazał na to Andrzej Zaborski, przedstawiając analityczny przegląd tych badań w zakresie Relacji Ibrahima ibn Jakuba o Słowianach. Nieznajomość wydania Tadeusza Kowalskiego na Zachodzie jest dość powszechna. Przyczyniamy się do tego sami utrzymującym się przekonaniem, że co na Zachodzie, to lepsze. Ostatni przykład takiej niewiedzy znajdujemy $\mathrm{u}$ wybitnego znawcy średniowiecznego piśmiennictwa arabskiego Fuata Sezgina, który w artykule o Ibrahime zamieszczonym w jego monumentalnym dziele pt. Geschichte des Arabischen Schriftums nawet nie wspomina wydania T. Kowalskiego. Uczony zamieścił tam jednak interesujące uwagi dotyczące Ibrahima, pisząc: „Die Vermutung halte ich für berechtigt, dass der Bischof Rabi 'b-Zaid die Delegation leitete, wobei Ibrāhīm als Dolmetscher oder hoher Beamter daran teilnahm"37. Takie stanowisko wydaje mi się najbardziej racjonalne, choć jest tylko prawdopodobną hipotezą, którą można wesprzeć analizą samych relacji przypisywanych Ibrahimowi.

Kilka słów o literaturze przedmiotu. Dysponujemy stosunkowo nowym opracowaniem na temat geografii arabskiej, w którym autorka omawia również relację Ibrahima ibn Jakuba ${ }^{38}$ i przypisuje mu autorstwo dzieła Księga dróg i krajów ${ }^{39}$. Przypisaniu Ibrahimowi dzieła al-Bekriego jest jakimś rozwiązaniem, gdybyż jeszcze mogło być poparte źródłami historycznymi.

Następnym źródłem, które zdaniem D.A. Sikorskiego źle zinterpretowałem, jest Kronika Thietmara. D.A. Sikorski, polemizując z moim tłumaczeniem tekstu Thietmara, nie przedstawia własnej analizy językowej tekstu, nie próbuje też dyskutować $\mathrm{z}$ moją. W zamian daje tłumaczenia tekstu w różnych językach i stwierdza, że różnią się od mojego. Co z tym robić? D.A. Sikorski argumentuje tak:

Moim zdaniem tekst autografu Thietmara w kodeksie drezdeńskim pozwala wyłącznie na pierwszą z dwóch interpretacji, gdyż zgodnie z tekstem z tej wersji tylko wysłannicy cesarza wzięli zakładników. Taką sytuację uznaje się za jednostronne gwarantowanie układu. Wedle przeprowadzonej przez E. Skibińskiego egzegezy wspomnianego passusu z pierwszej redakcji: „Każda ze stron musiała wybrać - do tego odnosi się electis - i zaakceptować - acceptis wybór drugiej strony. Można to rozumieć jako „kiedy wybrano zakładników /i/ zaakceptowano” (s. 26). Autor nie wyjaśnia, który fragment tekstu upoważnia go do stwierdzenia,

37 F. Segzin, Geschichte des Arabischen Schriftums, Bd. 15, t. 2, Frankfurt am Main 2010, s. $119 \mathrm{n}$.

38 E. Orłowska, Geografia regionalna $w$ kulturze arabsko-muzutmańskiej (VIII-XIVw.), Wrocław 2000.

39 Tamże, s. 111. 
że „Każda ze stron musiała wybrać” i zaakceptować wybór drugiej strony. To jest oczywisty (pozaźródłowy) domysł Autora, który nie ma podstaw w tekście, bo cały rozdział opowiada o działaniach wyłącznie wysłanników cesarskich ${ }^{40}$.

Tyle D.A. Sikorski. Powróćmy zatem do omawianego fragmentu, żebym mógł objaśnić moje stanowisko:

Cod. I

electisque obsidibus acceptis prefati seniores reversi sunt.

Cod.2.

electisque obsidibus acceptis ab invicem reversi sunt $t^{41}$.

Przetłumaczmy to dosłownie: „po wybraniu i zaakceptowaniu zakładników wcześniej wymienieni panowie powrócili”. Zastanówmy się, czego dotyczy ten tekst. Przyjmijmy, że dotyczy tylko jednej strony rokowań. Reversi sunt - powrócili oczywiście wysłannicy cesarza. Musieliby zatem wybrać i zaakceptować zakładników - sami? Bez niczyjej pomocy? Sami wybrali, a potem zgodzili się ze sobą? Po co mieliby akceptować własny wybór? Pamiętać należy, że Thietmar jest źródłem z tego samego roku, w którym zawarto pokój w Budziszynie. Nawet gdyby nie był, nie można dowolnie przestawiać słów w źródle historycznym. Gdyby zaś uznać, że electis odnosi się do posłów Chrobrego, a acceptis do posłów Henryka, to trzeba by jeszcze odpowiedzieć na pytanie, dlaczego Thietmar tego nie zaznaczył. Merseburski biskup zaznaczył swoją opinię o tym pokoju, twierdząc, że został zawarty non ut decuit, set sicut tunc fieri potuit - „nie tak jak należało, lecz tak jak wtedy można było uczynić”. Czy tak by ocenił fakt, że Chrobrego zmuszono jednostronnie do dania zakładników?

D.A. Sikorski jak zwykle imputuje mi nieznajomość poglądów, o których pisze, jednocześnie nie potrafi przedstawić argumentów cytowanych przez siebie autorów. W swojej recenzji, do której się odniosłem, pisał:

W roku 1993 Hartmut Hoffmann wysunąl nową hipotezę dotyczącą tzw. korwejskiej przeróbki Kroniki Thietmara, głównego źródła do najwcześniejszych dziejów w stosunkach polsko-niemieckich. Badacz ten, dokonawszy analizy różnic redakcyjnych między oryginałem zachowanym w kodeksie drezdeńskim będącym autografem Thietmara a ową przeróbką zachowaną w kodeksie brukselskim, doszedł do wniosku, że w tym drugim przypadku mamy do czynienia

40 D.A. Sikorski, O trzech najstarszych źródłach, s. 157.

41 Thietmari Merseburgensis Chronicon, ed. R. Holtzmann, Berlin 1935, 8,1, s. 492-493. 
również z redakcją autorską Thietmara, dokonaną, zdaniem Hartmanna, tuż przed śmiercią dziejopisarza ${ }^{42}$.

Oczywiście chodziło D.A. Sikorskiemu o Hartmuta Hoffmanna, a nie Hartmanna. Jest to zapewne błąd korekty. D.A. Sikorski zaznaczył niewielkie ograniczenia tej teorii w przypisie 118 w ten sposób: „Częściowa modyfikacja u Naß, Klaus, »Die Reichschronik des Annalista Saxo und die (pominięte w przypisie D.A. Sikorskiego - sächsische - E.S.) Geschichtsschreibung im 12. Jahrhundert. Hannover «, Hahn 1996, s. 144 n, który wykazuje, że część z drobnych poprawek z pewnością ma młodszą, nie Thietmarowską metrykę". W polemice ze mną zaś jest już odmiennego zdania: „Skibiński błędnie rozpoznał istotę problemu. Zdecydowana większość zmian w redakcji korwejskiej, znanej nam z kodeksu brukselskiego, nie ma nic wspólnego z Thietmarem" ${ }^{\prime 3}$.

Moja polemika nie dotyczyła poglądów D.A. Sikorskiego, a jedynie jego tekstu. $\mathrm{Z}$ H. Hoffmannem dyskutowałem tylko w zakresie mnie interesującym - analizowałem jedynie świadectwa dotyczące Polski. W tej analizie pokazałem, że redakcja korwejska nie ma znaczenia jako źródło historyczne do dziejów Polski. Tego stanowiska D.A. Sikorski nie podważył w swojej polemice. Warto jeszcze dodać, że w swoim artykule nie zanegowałem w całości argumentów Hoffmanna, bo nie zajmowałem się tym, co on. Stwierdziłem jedynie: „Jednak niekiedy argumentacja H. Hoffmanna nie da się utrzymać" ${ }^{44}$. Interesowało mnie wyłącznie to, czy zaakceptowanie drugiej wersji Thietmara tworzy nowe źródło historycznej do naszych dziejów.

Kolejnym źródłem, którego błędną interpretację stara się mi wykazać D.A. Sikorski, są Dzieje Sasów Widukinda. Polemista poruszał te sprawy w różnych miejscach, szerzej zwłaszcza w recenzji pracy Jarosława Sochackiego. Sens sporu ujmuje mój Adwersarz w polemice ze mną w charakterystycznym dla siebie stylu w ten sposób:

Podsumowując dyskusję w kolejnym tekście w polemice z J. Sochackim, którego notabene E. Skibiński nie zna, stwierdziłem, że „w sporze między Gerardem Labudą a Henrykiem Łowmiańskim, argumenty tego ostatniego w świetle stanu badań nad Dziejami saskimi Widukinda nie są pozbawione sensu, jak twierdził G. Labuda” i dalej „wykazuję tylko, że obie hipotezy opierają się na racjonalnych przesłankach" ${ }^{\prime 4}$.

\footnotetext{
42 D.A. Sikorski, O trzech najstarszych źródłach, s. 147.

43 Tamże, s. 149.

44 E. Skibiński, Mieszko I: Przyczynki do biografii, s. 24.

45 D.A. Sikorski, O trzech najstarszych źródłach, s. 155.
} 
W polemice z J. Sochackim jednak napisał inaczej: „J. Sochacki zapewne nie zdaje sobie sprawy, że stwierdzenie to stoi w jawnej sprzeczności z podstawowymi założeniami krytyki źródeł. Źródła zawsze muszą być poddane krytyce. W recenzji jako przykład zaniechań w analizie źródeł podałem problemy interpretacyjne wokół jednego z ustępów z dzieła Widukinda, starając się pokazać, że w sporze między Gerardem Labudą a Henrykiem Łowmiańskim argumenty tego ostatniego w świetle stanu badań nad »Dziejami《 saskimi Widukinda nie są pozbawione sensu, jak twierdził G. Labuda. Odrzucenie interpretacji Łowmiańskiego, jak to robi Autor, idąc tu za Labudą, nie jest po głębszej analizie problemu uzasadnione" ${ }^{46}$. Ponieważ jednak przytoczone przeze mnie proste argumenty nie zostały zrozumiane, spróbuję wyjaśnić szerzej moją koncepcję. Thietmar pisze, że Geron podjął swoje działania wobec Wichmana non inmemor iuramenti pamiętając o przysiędze. Jak to rozumieć? Objaśnienia dostarcza wcześniejsza opowieść Widukinda. Chodzi tu o przysięgę, którą złożył Wichman:

$958 \mathrm{r}$.

LX. Ductus exercitus contra Wichmannum tertia vice vix obtinuit, ut in fide Geronis filiqque sui susciperetur, ipsique apud imperatorem obtinerent, quo patris coniugisque patrimonio cum gratia imperiali frueretur. Iniussus sacramentum terribile dedit se contra imperatorem imperatorisque regnum numquam aliquid inique consilio aut actu facturum. Ita fide data in pace est dimissus et bonis promissionibus ab imperatore erectus.

Wichman więc przysięga powstrzymywać się od działań przeciwko cesarzowi Ottonowi I. Geron więc:

LXVI. Gero igitur comes non inmemor iuramenti, cum Wichmannum accusari vidisset reumque cognovisset, barbaris, a quibus eum assumpsit, restituit. Ab eis libenter susceptus longius degentes barbaros crebris preliis contrivit. Misacam regem, cuius potestatis erant Sclavi qui dicuntur Licicaviki, duabus vicibus superavit fratremque ipsius interfecit, predam magnam ab eo extorsit ${ }^{47}$.

Oddaje Wichmana barbarzyńcom, żeby ten podjął walkę na terenach barbarzyńców. Dalsza informacja pokazuje, że zamiar się udał, bo Wichman zamiast z cesarzem walczył z Mieszkiem, którego pokonał. Ten ostatni to jeden z owych longius

46 D.A. Sikorski, O (nieudanych) stosunkach polsko-niemieckich. Replika, Studia Historica Slavo-Germanica 29 (2013), s. 157.

47 Widukindi monachi Corbeiensis Rerum gestarum Saxonicarum libri III, ed. P. Hirsch i inni, Hannover 1935, 3, 66, s. 141. 
degentes barbaros - „dalej żyjących barbarzyńców”. Cała sprawa jest pokazana jako sukces Gerona, ale nie w walkach z Mieszkiem, lecz w pracy nad Wichmanem. Ta część kroniki Widukinda jest w dużej mierze poświęcona kłopotom z Wichmanem.

Nie rozpisywałem się na temat sukcesu księcia Hermana, stryja Wichmana, ale warto zwrócić uwagę na ujęcie ich przez Widukinda i przez Thietmara. W Dziejach Sasów konflikt ze słowiańskimi władcami rozpoczyna się w ten sposób:

LXVIII. Erant duo subreguli Herimanno duci, inimicitiae a patribus vicariae relicti;alter vocabatur Selibur, alter Mistav. Selibur preerat Waaris, Mistav Abdritis. Dum invicem quam saepe accusantur, victus tandem ratione Selibur condempnatus estquindecim talentis argenti a duce. Eam dampnationem graviter ferens arma sumerecontra ducem cogitavit ${ }^{48}$.

Herman więc występuje jako rozjemca w sporze dwóch władców i jednocześnie jako ich sędzia. Jest to zależność akceptowana przez obie strony i trwająca już jakiś czas. Spójrzmy teraz na tekst Thietmara w obu wersjach:

Cod. 1: (9)* Gero Orientalium marchio Lusizi et Selpuli, Miseconem quoque cum sibi subiectis imperiali subdidit dicioni. Herimannus dux Seliburem et Mistui cum suis imperatori tributarios fecit.

Cod. 2: Gero Orientalium marchio Lusizi et Selpuli, Miseconem quoque cum sibi subiectis impe ${ }^{*}$ riali subdidit dicioni. Heremannus dux Seluberem et Mistui cum sibi subditis imperatori tributarios fecit ${ }^{49}$.

Wedle tej wersji Herman ustanowił zależność trybutarną obu książąt. Jego sukces jest zestawiony z analogicznymi w tym kontekście dokonaniami Gerona. Czy zatem wersja Thietmara nie ma jakiejś podstawy historycznej, opartej choćby na wspomnieniach rodzinnych? Wbrew pozorom można na to pytanie odpowiedzieć $\mathrm{i}$ to negatywnie. Musimy jednak zacząć od relacji dalszych wydarzeń przez Widukinda:

Fuerunt etiam qui dicerent Sclavum speciem quidem belli gessisse, non verum bellum. Incredibile omnimodis fore hominem a puero bellis assuetum bellicas res tam male preparatas habuisse; sed id consilii machinatum ducem, ut quoquo pacto posset nepotem vinceret, ut saltem in patria salutem recuperaret, quam inter paganos penitus perdidisset ${ }^{50}$.

\footnotetext{
48 Widukindi monachi Corbeiensis, 3, 68, s. 142.

49 Thietmari Merseburgensis Chronicon, ks. 2, 14 (9), s. 54-55.

50 Widukindi monachi Corbeiensis, 3, 88, s. 143.
} 
Postawiono zatem zarzut, że Selibur podjął swoje działania dla wsparcia akcji księcia Hermana, który chciał swojego bratanka sprowadzić do ojczyzny. Chodziłoby w tym wszystkim zatem o zwabienie Wichmana. Rozmowa księcia Hermana z Seliburem została przedstawiona przez Widukinda w dalszej partii tego tekstu i jeszcze raz potwierdza taką interpretację:

Dux Sclavum austerius alloquens de perfidia et nequam eius actibus arguit, hocque ab eo responsi accepit: 'Quid me', inquit, 'de perfidia arguis? Ecce, quos nec tu nec dominus tuus imperator vincere potuistis, mea perfidia inermes assistunt. Ad haec dux conticuit, eum suae ditionis regione privans, filio ipsius, quem antea obsidem accepit, omni ipsius potestate tradita ${ }^{51}$.

Zatem status państwa Selibura nie zmienił się, a władzę ojca zastąpiono władzą syna. Przy czym otrzymał on taką samą władzę, jaką sprawował jego ojciec. Herman, który oskarżał słowiańskiego księcia, zamilkł i nie odpowiedział na jego zarzuty. Jak z tego widać, Widukind daje tu do zrozumienia, że cała akcja została przeprowadzona po to, aby złapać Wichmana. Cała wojna była wojną nieprawdziwą - non verum bellum. Nie zmieniła też tak naprawdę statusu obu władców słowiańskich, jak chce Thietmar, twierdząc, że: Herimannus dux Seliburem et Mistui cum suis imperatori tributarios fecit. Selibur został zastąpiony przez syna, a cała akcja miała na celu złapanie Wichmana przez jego stryja Hermana. Parafrazując, mogę odpowiedzieć, że D.A. Sikorski zapewne nie zdaje sobie sprawy, że usuwanie z kroniki fragmentu, żeby dopasować źródło do naszych koncepcji nie należy do krytyki źródeł i stoi w sprzeczności z jej podstawowymi założeniami. Taka kombinacja jest też sprzeczna z tekstem Widukinda, w którym Wichman odgrywa ważną rolę. Przeciwnie zgadza się z Thietmarem, który prawie usunął wątek Wichmana ze swojej opowieści o jego epoce. Fantazyjna propozycja Henryka Łowmiańskiego, postulującego usunięcie niewygodnego fragmentu źródła, może więc zostać ostatecznie usunięta. Dowodnie pokazuje to historia o dwóch władcach słowiańskich i księciu Hermanie, stryju Wichmana. Widukind przedstawia to jako intrygę, której celem miało być schwytanie Wichmana. Thietmar sprowadza tylko do wzmianki o zmuszeniu obu władców do płacenia trybutu.

Powróćmy do argumentacji D.A. Sikorskiego:

E. Skibiński (podobnie jak K. Tymieniecki) za sprzeczne uznaje również obszerną opowieść Widukinda o księciu Hermanie i dwóch „królewiątkach” Słowiańskich z Połabia (III, 69), z jednozdaniowym jej streszczeniem Thietmara

Tamże. 
z czym trudno się zgodzić. Działania księcia Hermana Billunga wobec „królewiąt" (funkcja rozjemcza i możliwość nakładania kary) wskazują, że byli podporządkowani cesarzowi nawet, jeśli w tej opowieści słowo trybutariusze nie pada, to $\mathrm{w} \mathrm{X}$ w. nie znamy ze strony cesarza innej formy narzucania zwierzchności nad Słowianami niż trybut. Thietmar jednym zdaniem ująt istotę sprawy ${ }^{52}$.

D.A. Sikorski źle zrozumiał moją argumentację. Z tekstu Widukinda wynika, że obaj książęta pozostawali w zależności od cesarza już wcześniej. W tym sensie interwencja Hermana niczego nie zmieniła w ich stosunkach. Syn Selibura rządził na tych samych zasadach co jego ojciec - omni ipsius potestate tradita - jak to objaśnia Widukind.

Przystępując do badań historycznych, musimy zdawać sobie sprawę z tego, jakimi źródłami dysponujemy oraz jaki jest stan badań. To drugie zadanie może się wydawać trudne, wobec wielości publikacji naukowych. Jednak stan badań, który musimy uwzględnić, dotyczy tylko tego zakresu dziejów, który nas interesuje. Nikt, kto zajmuje się św. Stanisławem, nie potrzebuje wiedzy na temat całej dyskusji naukowej wokół kroniki Anonima Galla czy mistrza Wincentego. Jeśli jednak pragnie odwołać się do tej dyskusji, to musi pokazać, dlaczego jest ona ważna dla jego tematu. Dlatego punktem wyjścia zawsze muszą być źródła - takie, jakimi dysponujemy. Badacze dla rozwiązania rozmaitych problemów historycznych zawsze tworzyli konstrukcje wyjaśniające. Te konstrukcje z czasem były weryfikowane przez ich następców i odrzucane. Dzisiaj stanowią przedmiot badań historyków historiografii, badaczy imaginarium ideowego minionych epok.

Wyjaśnienia, które tu przedstawiłem, zamykają, jak sądzę, dyskusję nad tekstami Widukinda i Thietmara w zakresie nas tu interesującym. Rzecz o Słowianach w opracowaniu al-Bekriego wymaga jednak jeszcze dalszych studiów. Przede wszystkim potrzebujemy opracowania testimoniów do życia i prac tego autora i innych autorów tej epoki działających w Andaluzji. Prowadzi nas to do biografistyki arabskiej, która sama przedstawia odrębny przedmiot badań. Stan dyskusji nad przekazami przypisywanymi Ibrahimowi ibn Jakubowi jest niezadowalający z różnych powodów. Trudno go jednak poprawić, gdy autorzy piszący na ten temat nie znają prac innych zajmujących się tymi zagadnieniami. Naprawienie tej sytuacji wymaga zgromadzenia podstawowych opracowań i być może wydania antologii najważniejszych prac zagranicznych na ten temat. Należy tu położyć nacisk na prace autorów środkowo- i wschodnioeuropejskich, którzy z natury rzeczy byli najbardziej zainte- 
resowani tym tematem. Wznowienie edycji T. Kowalskiego i jej publikacja w języku angielskim na pewno przyczyniłyby się do poprawy obecnego stanu rzeczy.

Dr hab. Edward Skibiński, prof. UAM

Uniwersytet im. Adama Mickiewicza w Poznaniu

Wydział Historii

ul. Uniwersytetu Poznańskiego 7

61-614 Poznań

e-mail: edward_skibinski@yahoo.com

Nadesłany 17 VII 2020

Zaakceptowany 10 VIII 2020 